\title{
Meiotic analysis of the germoplasm of three medicinal species from Asteraceae family
}

\author{
Análise meiótica do germoplasma de três espécies medicinais da família Asteraceae
}

\author{
Denise Olkoski ${ }^{\mathrm{I}}$ Haywood Dail Laughinghouse ${ }^{\mathrm{II}}$ Antonio Carlos Ferreira da Silva \\ Solange Bosio Tedesco ${ }^{\mathrm{I}^{*}}$
}

\section{ABSTRACT}

Cytogenetic characterization was carried out on 12 accessions from Aster squamatus (Spreng.) Hieron., Pterocaulon polystachyum DC, and Solidago microglossa DC by studying their meiotic behavior and pollen viability. These species are from the Asteraceae family, native to Rio Grande do Sul State, Brazil, and are important for medicinal use. Young inflorescences with four accessions of each species were collected, fixed in ethanol-acetic acid (3:1), and conserved in ethanol $70 \%$ until use. The method used was that of squashing the anthers and coloring with acetic orcein 2\%. Meiosis was regular in all accessions, presenting chromosomal associations preferentially bivalent, where $n=10$ was found for Aster squamatus and $n=9$ for Pterocaulon polystachyum, and Solidago microglossa. The studied accessions presented a Meiotic Index (MI) that varied from $65 \%$ to $87 \%$ in Aster squamatus, $85 \%$ to $92 \%$ in Pterocaulon polystachyum, and $64 \%$ to $92 \%$ in Solidago microglossa, indicating meiotic stability, although irregularities appeared during the cellular division. The pollen viability estimative was high in all studied accessions. These results indicate that the studied species can be included in future studies of genetic breeding.
\end{abstract}

- NOTA -
Key words: Asteraceae, meiotic behavior, pollen viability.

\section{RESUMO}

Foi realizada a caracterização citogenética de doze acessos de Aster squamatus, Pterocaulon polystachyum $e$ Solidago microglossa, espécies da família Asteraceae, nativas do Rio Grande do Sul, Brasil, por meio do estudo do comportamento meiótico e da viabilidade polínica, que possuem grande importância para uso medicinal. Inflorescências jovens de quatro acessos de cada espécie foram fixadas em álcool-ácido acético (3:1) e conservadas em álcool $70 \%$ até o uso. O método utilizado foi o de esmagamento de anteras e a coloração com orceína acética $2 \%$. A meiose foi regular em todos os acessos, apresentando associações cromossômicas preferencialmente em bivalentes, encontrandose $n=10$ para Aster squamatus e $n=9$ para Pterocaulon polystachyum e Solidago microglossa. Os acessos apresentaram índice meiótico que variou de 65\% a 87\% em Aster squamatus, de $85 \%$ a 92\% em Pterocaulon polystachyum e de $64 \%$ a 92\% para Solidago microglossa, indicando estabilidade meiótica, apesar de o aparecimento de irregularidades durante a divisão celular. A estimativa da viabilidade polínica foi alta para todos os acessos estudados. Esses resultados indicam que as espécies estudadas podem ser incluídas em futuros trabalhos de melhoramento genético.

Palavras-chave: recursos genéticos, comportamento meiótico, viabilidade polínica.

In Brazil, popular medicine is much diffused since there are many potential medicinal plants, for this, studies on germoplasm characterization are necessary, including these plants in genetic breeding programs.

Aster squamatus is a plant native to Rio Grande do Sul State, popularly known as 'Zé da Silva' and 'Miracle Herb'. In popular medicine, this plant is used as an anti-diarrheic, anti-tumoral, and to promote scabbing (KARNIKOWSKI, 1996). Pterocaulon polystachyum is known by its popular name 'boldodo-campo, doce-amargo do campo’ (BACKES \&

IDepartamento de Biologia, Centro de Ciências Naturais e Exatas (CCNE), Universidade Federal de Santa Maria (UFSM), 97105900, Santa Maria, RS, Brasil. E-mail: stedesco@smail.ufsm.br. *Autor para correspondência.

IIJohn Carroll University, University Heights, OH 44118, USA. E-mail: hdliv@hotmail.com. 
NARDINO, 1999) or 'pitoco or quitoco'. It's popularly used for treating digestive disturbances and external wounds (LOPES, 1995). Solidago microglossa is known as 'erva-lanceta'. The flowers are used in infusions and indicated for acne, contusions, and stomach infections (ALMEIDA, 1993).

Cytogenetic studies of Aster squamatus ( $\mathrm{n}=10$ ) were carried out by TALAVERA et al. (1994) and SPOONER et al. (1995). For Pterocaulon polystachyum, reports on chromosomal studies were not found in literature, reinforcing the need for these investigations, however there are reports on Pterocaulon lanatum Kuntze ( $\mathrm{n}=11$ ) by WULFF et al. (1996) and Pterocaulon virgatum $(\mathrm{n}=10)$ (IPCN).

Solidago microglossa $(\mathrm{n}=9)$ and Solidago chilensis Meyen ( $\mathrm{n}=9$ ) were studied by TURNER et al. (1979) as different species. HUNZIKER et al. (1989) only studied Solidago chilensis $(\mathrm{n}=9)$.

The objective of this research was to analyze meiotic behavior of medicinal species from the Asteraceae family, native to Rio Grande do Sul State, since they posses a large importance to popular medicine.

Twelve accessions of the studied species were collected in the municipal of Santa Maria, Rio Grande do Sul, Brazil (Table 1). Each one of these accessions was registered in the Herbarium SMDB (Santa Maria Department of Biology). From these same accessions, the young plant inflorescences were collected for latter meiotic analysis and pollen viability estimative. Soon after collected, the inflorescences were fixed in ethanol-acetic acid 3:1 for 24 hours at room temperature, then transferred to ethanol $70 \%$, maintained at a temperature of $4{ }^{\circ} \mathrm{C}$ until slides were prepared. For meiotic analysis, slides were prepared using the method of squashing the anthers and coloring with acetic orcein $2 \%$ (GUERRA \& SOUZA, 2002). Five slides were observed per accession that presented meiosis phases with good chromosomal visualization in optic microscopes and the best cells were photographed. For pollen viability estimative, the same method used for meiosis analysis was applied, with delimitation, at random, of six visual fields on each slide. Five hundred pollen grains were counted per studied accession.

The obtained results from the studies on meiotic behavior, meiotic index, and pollen viability from the 12 accessions of the following species: Aster squamatus, Pterocaulon polystachyum, and Solidago microglossa are presented in table 1.

The meiotic analysis of Aster squamatus showed 10 chromosomes in bivalent associations (II) in diakinesis and metaphase 1 (Figure 1a), normal chromosomal segregation in anaphase 1 (Figure1b) and telophase 1 , and retarding chromosomes in telophase

Table 1 - Meiotic associations, chromosomal segregation, meiotic index, and pollen viability index of A. squamatus, P. polystachyum, and S. microglossa, collected in Santa Maria, RS, Brazil.

\begin{tabular}{|c|c|c|c|c|c|c|c|c|c|}
\hline \multirow[b]{2}{*}{ Specie/accession } & \multirow{2}{*}{$\begin{array}{c}\text { Registry } \\
\text { number }\end{array}$} & \multirow{2}{*}{$\begin{array}{c}\text { Total cell } \\
\text { number }\end{array}$} & \multirow[b]{2}{*}{ CA } & \multicolumn{4}{|c|}{-------------Cell number------------- } & \multirow[b]{2}{*}{ MI (\%) } & \multirow{2}{*}{$\begin{array}{l}\text { Pollen viability } \\
\text { estimative (\%) }\end{array}$} \\
\hline & & & & $\begin{array}{l}\text { Diak } \\
\text { /met I }\end{array}$ & $\begin{array}{c}\text { Ana I/ } \\
\text { Tel I }\end{array}$ & Met II & $\begin{array}{c}\text { Ana II/ } \\
\text { Tel II }\end{array}$ & & \\
\hline A. squamatus/1 & 10291 & 121 & $10 \mathrm{II}$ & 38 & 9 & 4 & 13 & 65 & 97.83 \\
\hline A. squamatus/2 & 10060 & 241 & $10 \mathrm{II}$ & 52 & 45 & 7 & $67^{\mathrm{a}}$ & 87 & 98.26 \\
\hline A. squamatus/3 & 9693 & 524 & $10 \mathrm{II}$ & 74 & 41 & 20 & $74^{\mathrm{b}}$ & 74 & 98.26 \\
\hline A. squamatus/4 & 10292 & 275 & $10 \mathrm{II}$ & 41 & 24 & 9 & $89^{c}$ & 78 & 98.63 \\
\hline P. polystachyum/1 & 9676 & 64 & 9 II & 5 & 19 & 4 & 22 & 92 & 99.6 \\
\hline P. polystachyum/2 & 10044 & 86 & $9 \mathrm{II}$ & 7 & 29 & 6 & 35 & 88 & 99.2 \\
\hline P. polystachyum/3 & 10293 & 112 & $9 \mathrm{II}$ & 23 & $46^{\mathrm{de}}$ & 2 & 27 & 85 & 99.4 \\
\hline P. polystachyum/4 & 9673 & 65 & 9 II & 5 & 16 & 9 & 12 & 86 & 99.6 \\
\hline S. microglossa/1 & 10294 & 699 & 9 II & 147 & 64 & - & 108 & 64 & 100 \\
\hline S. microglossa/2 & 9690 & 1094 & 9 II & 324 & 143 & - & 40 & 92 & 99.6 \\
\hline S. microglossa/3 & 9928 & 231 & $9 \mathrm{II}$ & $23^{f}$ & 37 & 1 & 10 & 80 & 99.9 \\
\hline S. microglossa/4 & 10295 & 498 & $9 \mathrm{II}$ & $25^{\mathrm{g}}$ & 39 & 3 & $22^{\mathrm{h}}$ & 92 & 99.8 \\
\hline
\end{tabular}

II= bivalent, ${ }^{\text {a }} 4$ cells with irregularities, telophase II with 3 poles, ${ }^{\text {b }} 9$ cells with irregularities, telophase II with 3 poles, ${ }^{\text {c }} 6$ cells with irregularities, 5 telophases II with 3 poles and 1 retarding chromosome, ${ }^{\mathrm{d}} 1$ cell with irregularity, anaphase I with 1 retarding chromosome, ${ }^{\mathrm{e}} 1$ cell with irregularity, telophasic bridge, ${ }^{\mathrm{f}} 4$ cells with irregular meiotic configurations, ${ }^{\mathrm{g}} 6$ cells with irregular meiotic configurations, and ${ }^{\mathrm{h}}$ cells with irregularities, telophase II with 3 poles.

CA: Chromosomal association; Diak.Met I: Diakinesis/Metaphase I; Ana I/ Tel I: Anaphase I/ Telophase I; Met II: Metaphase II; Ana II/Tel II: Anaphase II/ Telophase II; MI: Meiotic Index. 


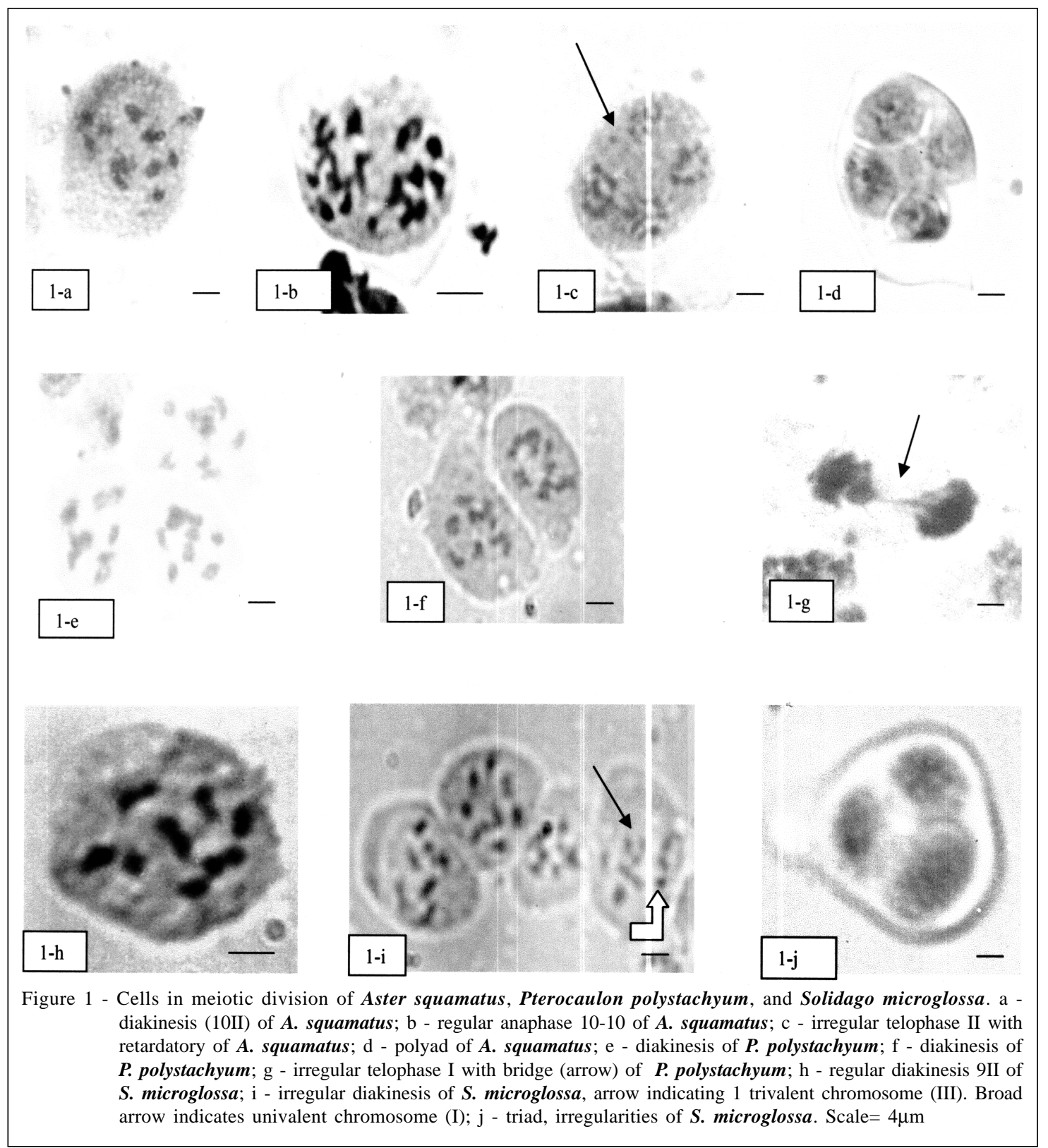

II (Figure 1c), as well as cells with 3 poles (Table 1 ), and one cell with 5 (Figure 1d).

The MI from Aster squamatus accession 1 presented the last value, $65 \%$, among all the accession of this species, and the pollen availability was above 97.83\% (Table 1). The accession of Aster squamatus presented regular meiosis with 10 bivalents (II) in all the studies populations, according to presented results (Table 1). Other authors like TALAVERA et al. (1994), reported $\mathrm{n}=10$ as the gametic number for this species. Nevertheless, SPOONER et al. (1995) found $n=5$, which doesn't agree with the cited authors and with our results presented in table 1 , where bivalent associations of chromosomes in diakinesis $(n=10)$ can be observed, therefore the studies accessions possess $2 n=20$, in this study considered diploid, even though discussion suggest that this is the probable tetraploid level. DILLON \& TURNER (1982) distinguished the South American species from the North American species as Aster subulatus Michx., which are $n=5$ and $n=10$ for tetraploids. SPOONER et al. (1995) considered $n=5$ for Aster squamatus, suggesting the occurrence of intraspecific diploidy and tetraploid cytotypes would have independently evolved within each taxon.

In the studied accessions from Pterocaulon polystachyum (Table 1), the following were observed: 
9 bivalent chromosomes (II) in diakinesis and metaphase 1 (Figure 1e, 1f), and normal chromosomal segregation in anaphase and telophase I and II (9-9), even though some irregularities occurred, like a telophasic bridge (Figure 1g) and a retarding chromosome in one cell. The MI was above $85 \%$ and pollen viability was greater than $99.2 \%$ (Table 1 ).

The accessions of Pterocaulon polystachyum presented regular meiosis with 9 bivalents (II) (Table 1). The chromosomal number determination carried out in this study is the first record for the species. Through meiosis analysis, the gametic number $n=9$, consequently $2 n=18$ was indicated. Though this species does not present chromosomal studies in literature, until now, results on other species from the genus Pterocaulon were analyzed. Pterocaulon lanatum presented $\mathrm{n}=11$ (WULFF et al. 1996) and Pterocaulon virgatum (L.) $D C n=10$ (IPCN), which differ from our studies, showing that interspecific variability exists within species of this genus.

In Solidago microglossa, 9 bivalent chromosomes (II), in diakinesis and/or metaphase I (Figure 1h), were observed in the majority of the cells. However, some cells showed irregularities (Figure 1i) in pairing $(14 \mathrm{II}+1 \mathrm{III}+1 \mathrm{I})$. The chromosomal segregation was normal in anaphase and telophase I and II (9-9), however, triads were formed (Figure 1j). The MI varied between $64 \%$ and $92 \%$, while the pollen viability was higher then $99.6 \%$ (Table 1 ).

The accessions from Solidago microglossa indicated 9 bivalent chromosomes (II) in regular meiosis (Table 1). Studies on Solidago chilensis, considered a synonym (LORENZI, 2002), was carried out by HUNZIKER et al. (1989) that also found $n=9$.

The number of irregular tetrads in one of the accessions from Aster squamatus and in one from Solidago microglossa demonstrated a low MI (65\% and $64 \%$, respectively), indicating the probability of some infertile pollen grains or some with low fertility. However, in this study, the pollen viability was only inferred by estimative using the staining method, which indicated high viability.

From the results it was concluded that Pterocaulon polystachyum can be considered having $2 \mathrm{n}=18$ chromosomes in diploid level. The Aster squamatus and Solidago microglossa species had presented gametic number $n=10$ and $n=9$, respectively. All the accessions of the studied species presented regular meiosis and a high pollen viability estimative.
These obtained results suggest that these species can be included in genetic breeding programs.

\section{ACKNOWLEDGEMENTS}

The authors are thankful to Dr. Thais Scotti do Canto-Dorow for the botanic identification.

\section{REFERENCES}

ALMEIDA, E.R. Plantas medicinais brasileiras, conhecimentos populares e científicos. São Paulo: Hemus, 1993. 341p.

BACKES, A.; NARDINO, M. Nomes populares e científicos de plantas do Rio Grande do Sul. Porto Alegre: Unisinos, 1999. 202p.

DILLON, M.; TURNER, B.L. Chromosome numbers of peruvian Cornpositae. Rhodora, v.84, p.131-137, 1982.

GUERRA, M.; SOUZA, M.J. Como observar cromossomos: um guia de técnica em citogenética vegetal, animal e humana. São Paulo: FUNPEC, 2002. 131p.

HUNZIKER, J.H. et al. Estudios cariologicos en Cornpositae V. Darviniana, v.29, n.1-4, p.25-39,1989.

IPCN. Index to plant chromosome number. 1984. Capturado em 22 abr. 2007. On-line. Disponível em http:// mobot.mobot.org/W3T/Search/ipcn.html.

KARNIKOWSKI, M. Contribuição ao estudo fitoquímico e farmacológico de Aster squamatus (Spreng.) Hieron. (Asteraceae). 1996. 79f. Dissertação (Mestrado em Ciência e Tecnologia Farmacêuticas) -Universidade Federal de Santa Maria.

LOPES, A.M.V. Plantas usadas na medicina popular do Rio Grande do Sul. Santa Maria: UFSM, 1995. 74p. (Caderno Técnico)

LORENZI, H. Plantas medicinais do Brasil: nativas e exóticas cultivadas. Nova Odessa, São Paulo: Instituto Plantarum, 2002. 512p.

SPOONER, D.M. et al. Chromosome counts of Compositae from Equador and Venezuela. Annals of the Missouri Botanical Garden, v.82, p.596-602, 1995.

TALAVERA, 5. et al. Notas cariológicas sobre algunas compuestas de Marruecos. Acta Botânica Malacitana, v.19, p.97-101, 1994.

TURNER, B.L. et al. Chromosome numbers in south American Compositae. American Journal of Botany, v.66, n.2, p.173178, 1979.

WULFF, A. et al. Estudios cariológicos en Compositae VII. Darviniana, v.34, n.1-4, p.213-231, 1996. 